\title{
TINJAUAN YURIDIS TANGGUNGJAWAB PERUSAHAAN PENYEDIA JASA PT GOLGON AKIBAT TINDAK PIDANA PENCURIAN DILAKUKAN PEKERJA/SATPAM
}

\author{
Oleh: \\ Muhammad Yasid Nasution \\ Dody Suryandi \\ Universitas Darma Agung, Medan \\ ABSTRACT
}

Article 65, paragraph 6, the work relationship in the implementation of the work as meant in paragraph 1 is regulated in a written work agreement between the other company and the workers it employs. Article 66 paragraph (1) of the Manpower Law, for example, stipulates that outsourcing may only be carried out for supporting service activities or activities that are not directly related to the production process. Security guard is an employee who maintains security and order in the environment / workplace which includes aspects of physical security, personnel, information and other technical security.

\section{Keywords: PT GOLGON, Security Guard Provider, Theft Crime}

\begin{abstract}
ABSTRAK
Pasal 65 ayat 6 hubungan kerja dalam pelaksanaan pekerjaan sebagaimana dimaksud dalam ayat 1 diatur dalam perjanjian kerja secara tertulis antara perusahaan lain dan pekerja yang dipekerjakannya. Pasal 66 ayat (1) UU Ketenagakerjaan misalnya yang mengatur bahwa outsourcing hanya boleh dilakukan untuk kegiatan jasa penunjang atau kegiatan yang tidak berhubungan langsug dengan proses produksi. Satpam adalah pegawai yang menyelenggarakan keamanan dan ketertiban di lingkungan/tempat kerjanya yang meliputi aspek pengamanan fisik, personel, informasi dan pengamanan teknis lainnya.
\end{abstract}

Kata Kunci: PT GOLGON, Penyedia Satpam, Tindak Pidana Pencurian

\section{A. PENDAHULUAN}

Satpam adalah pegawai yang menyelenggarakan keamanan dan ketertiban di lingkungan/tempat kerjanya yang meliputi aspek pengamanan fisik, personel, informasi dan pengamanan teknis lainnya. Pengamanan swakarsa yang dikenal satpam merupakan salah satu pihak yang turut mengemban fungsi
Kepolisian. Satpam sebagai salah satu bentuk pengamanan swakarsa mempunyai fungsi yang sama dengan polisi, hanya saja terbatas pada lingkungan tempatnya bertugas.

Bentuk-bentuk pengamanan swakarsa adalah suatu bentuk pengamanan yang diadakan atas kemauan, kesadaran, dan kepentingan masyarakat sendiri yang kemudian 
memperoleh pengukuhan dari Kepolisian Negara Republik Indonesia, seperti satuan pengamanan lingkungan dan badan usaha di bidang jasa pengamanan.

\section{Bentuk-bentuk pengamanan swakarsa memiliki kewenangan kepolisian terbatas dalam lingkungan kuasa tempat meliputi lingkungan pemukiman, lingkungan kerja, lingkungan pendidikan. Contohnya adalah satuan pengamanan lingkungan di pemukiman, satuan pengamanan pada kawasan perkantoran atau satuan pengamanan pada pertokoan. Pengaturan mengenai pengamanan swakarsa merupakan kewenangan Kapolri.}

Dalam hal penegakan peraturan perundang-undangan tentunya juga memiliki kewenangan tersebut dengan dasar untuk menjaga keamanan dan ketertiban. Hal tersebut diperkuat dengan adanya mata ajaran atau kegiatan mengenai Penangkapan dan Penggeledahan pada jenjang pelatihan Gada Pratama untuk kemampuan dasar dalam Satuan Acara Pelajaran Pelatihan Satuan Pengamanan yang dapat dilihat dari Bab IV Huruf B Lampiran Peraturan Kapolri 24/2007.

Tidak terdapat sanksi yang tegas mengatur bilamana perusahaan melakukan pelanggaran terkait kontrak PKWT tersebut. Sanksinya, hanya berupa kontrak lama batal demi hukum dan langsung berlaku skema PKWTT. Sebagai pelaksana penyerahan pekerja kepada perusahaan lain melalui perjanjian pemborongan menyangkut kepentingan buruh dan pengusaha. Karena Pasca keluarnya MK No 27/PUU-X/2011 tentang pembatalan Pasal 65 ayat 7 dan Pasal 66 ayat 2 huruf $b$ tidak diperbolehkan lagi pekerjaan utama untuk outsourcing.

PT Golgon adalah salah satu perusahaan outsourcing yang bergerak dibidang jasa perabotan alat rumah tangga, hotel dan satpam. Banyak satpam yang diserap dalam perusahaan ini. Perusahaan PT Golgon mempekerjakan satpam dengan sistem PKWT. Metode yang digunakan adalah rasa yang paling tepat dan efisien untuk mendapatkan karyawan sesuai dengan kebutuhan perusahaan. Rekrutmen adalah proses menentukan dan menarik pelamar yang mampu bekerja dalam suatu perusahaan. Hasilnya calon karyawan baru untuk diseleksi dan dipilih.

Satpam yang dipilih dengan cara rekrutmen, harus mereview dan memperbarui uraian pekerjaan dan spesifikasi untuk posisi satpam di perusahaan PT Golgon. Dengan seleksi administrasi yang dilakukan, melampirkan Surat Lamaran Kerja, CV, Ftokopi KTP, Pasfoto terbaru, fotokopi ijasah dan transkip yang dilegalisir, medical check up, dan latihan baris berbaris (PBB).

Setiap Satpam wajib mematuhi ketentuan berperilaku (Code of Conduct). Dalam Pasal 10 huruf c Peraturan Kepala Kepolisian Negara Republik Indonesia No. 8 Tahun 2009 tentang Implementasi Prinsip dan Standar Hak Asasi Manusia dalam Penyelenggaraan Tugas Kepolisian Negara Republik Indonesia diantaranya adalah tidak boleh menggunakan kekerasan, kecuali dibutuhkan untuk mencegah kejahatan membantu melakukan penangkapan terhadap pelanggar hukum atau tersangka sesuai dengan peraturan penggunaan kekerasan, 
Seorang petugas jasa atau security menampar orang yang yang berada di luar lingkup pekerjaan dengan alasan mendapat laporan dari salah satu pekerja bangunan atas perlakuan yang ia terima. Namun, laporan yang ia berikan ternyata keliru (tidak sesuai fakta), kemudian korban yang ditampar melaporkan kejadian ini pada pihak yang berwajib. Apakah si petugas jaga ini termasuk melakukan tindak penganiayaan.

Ada beberapa ketentuan dalam UU Ketenagakerjaan yang mengatur mengenai sanksi perdata pasal 59 ayat (7) UU Ketenagakerjaan, di samping itu, para pihak juga harus memperjanjikan konsekuensi perdata lainnya dalam perjanjian kerja (PK) dan/atau dalam peraturan perusahaan/perjanjian kerja bersama (PP/PKB) bila terjadi wanprestasi. Sedangkan, sanksi pidana dan sanksi administratif diatur dalam pasal $183 \mathrm{~s} / \mathrm{d}$ pasal 189 serta pasal 190 UU Ketenagakerjaan.

Berdasarkan pasal 57 UU No. 2 Tahun 2004 tentang Penyelesaian Perselisihan Hubungan Industrial (UU PPHI), apabila terjadi perselisihan hubungan industrial sampai di Pengadilan Hubungan Industrial (PHI) hukum acara yang berlaku adalah Hukum Acara Perdata yang berlaku pada Pengadilan dalam lingkungan Peradilan Umum meliputi HIR/RBG), kecuali diatur secara khusus dalam Undang-undang ini.

Namun, dalam hal terjadi tindak pidana terkait ketentuan dalam hukum ketenagakerjaan, karena tidak diatur secara khusus dan tidak dikesampingkan ketentuan umum, maka tentu prosedur beracara yang berlaku adalah hukum formal yang diatur dalam KUHAP. Sedangkan, sanksi administratif diamanatkan untuk diatur dalam Peraturan Menteri Tenaga Kerja dan Transmigrasi, walaupun hingga saat ini belum diatur secara khusus, namun ada beberapa Peraturan Menteri yang isinya telah mencantumkan konten sanksi administratif.

Sanksi Pasal 59 UU Ketenagakerjaan jika memang PKWT bertentangan dengan UU maka PKWT itu batal demi hukum berubah menjadi PKWTT. Walaupun demi hukumnya tidak secara otomatis berubah, pekerja dapat mengajukan gugatan ke pengadilan untuk mendapatkan hak itu.

\section{B. Rumusan Masalah}

1. Bagaimana Pengaturan Hukum Satpam menurut peraturan perundangundangan di Indonesia?

2. Bagaimana Kriteria Tindak Pidana Yang Dilakukan Pekerja Satpam Dan Sanksi Yang Dikenakan Kepada Pekerja Satpam?

3. Bagaimana Tanggungjawab Perusahaan Penyedia Jasa Akibat Tindak Pidana Yang Dilakukan Pekerja Satpam?

\section{Tujuan Penelitian}

1. Untuk Mengetahui Pengaturan Hukum Satpam menurut peraturan perundangundangan di Indonesia.

2. Untuk Mengetahui Kriteria Tindak Pidana Yang Dilakukan Pekerja Satpam Dan Sanksi Yang Dikenakan Kepada Satpam.

3. Untuk Mengetahui Tanggungjawab Perusahaan Penyedia Jasa PT Golgon 
Akibat Tindak Pidana Pencurian Yang Dilakukan Satpam.

\section{Metode Penelitian}

Jenis penelitian yang digunakan adalah jenis penelitian hukum normatif (doktrinal) yaitu penelitian dilakukan melalui studi kepustakaan (library research). Pada penelitian hukum jenis ini, hukum dikonsepkan sebagai apa yang tertulis dalam peraturan perundang-undangan (law in books) atau hukum dikonsepkan sebagai kaidah atau norma yang merupakan patokan berprilaku manusia yang dianggap pantas.

\section{Sifat Penelitian}

Sifat penelitian yang digunakan dalam penelitian ini adalah bersifat deskriptif.

\section{Jenis Data dan Sumber Data}

Data yang digunakan dalam penelitian ini adalah data sekunder yang bersumber dari studi kepustakaan. Data sekunder antara lain mencakup dokumen-dokumen resmi, buku-buku, hasil-hasil penelitian yang berwujud laporan, dan sebagainya. Ciri-ciri umum data sekunder adalah sebagai berikut:

1. Pada umumnya data sekunder dalam keadaan siap terbuat dan dapat dipergunakan dengan segera;

2. Baik bentuk maupun isi data sekunder, telah dibentuk dan diisi oleh peneliti-peneliti terdahulu, sehingga peneliti kemudian, tidak mempunyai pengawasan terhadap pengumpulan, pengolahan, analisis maupun konstruksi data;

3. Tidak terbatas oleh waktu dan tempat.

Jenis data sekunder yang digunakan dalam penelitian ini adalah terdiri dari bahan-bahan hukum seperti berikut:

1) Undang-undang Ketengakerjaan Nomor 13 Tahun 2003 yakni Pasal 64, 65 dan 66, UndangUndang Nomor 21 Tahun 2000 Tentang Serikat Pekerja/Serikat Buruh

2) Undang-Undang Nomor 13 Tahun 2003 tentang Ketenagakerjaan

3) Undang-undang Nomor 2 Tahun 2003 tentang Kepolisian

4) Surat Keputusan Kepala Kepolisian No Pol: Skep/1017/XII/2002 tentang Kurikulum Pelatihan Satuan Pengamanan.

5) Surat Keputusan Kepala kepolisian No Skep/1020/XII/2002 tentang Registrasi Satuan-satuan Pengamanan

6) Peraturan Kepala Kepolisian No 24 Tahun 2007 tentang Sistem Manajemen Pengamanan Organisasi Perusahaan dan Instansi

7) Peraturan Menteri Tenaga Kerja dan Transmigrasi Nomor 19 Tahun 2012 tentang SyaratSyarat Penyerahan Sebagian Pelaksanaan Pekerjaan Kepada Perusahaan Lain

8) Surat Edaran Menteri Tenaga Kerja dan Transmigrasi Nomor SE.04/MEN/VIII/2013 tentang Pedoman Pelaksanaan Peraturan Menteri Tenaga Kerja dan Transmigrasi Nomor 19 Tahun 2012 tentang Syarat-Syarat 
Penyerahan Sebagian

Pelaksanaan Pekerjaan Kepada

Perusahaan Lain. dan Keputusan Menteri Tenaga Kerja dan Transmigrasi Nomor 101/menteri/VI/2004 Tahun 2004 tentang Tata Cara Perijinan Perusahaan Penyedia Jasa Pekerja/Buruh dan KUHP.

\section{E. HASIL PENELITIAN DAN PEMBAHASAN}

\section{Pengaturan Hukum Pengamanan Swakarsa Menurut Peraturan Perundang-Undangan Di Indonesia}

Tugas pokok Satpam adalah menyelenggarakan keamanan dan ketertiban di lingkungan/tempat kerjanya yang meliputi aspek pengamanan fisik, personel, informasi dan pengamanan teknis lainnya.

Fungsi
melindungi dan mengayomi
lingkungan/tempat kerjanya dari setiap gangguan keamanan, serta menegakkan peraturan dan tata tertib yang berlaku di lingkungan kerjanya;

Pasal 16 ayat (1) Peraturan Pelaksana No. 43/2012 dikatakan bahwa terdapat pengawasan terhadap pengamanan swakarsa dalam bentuk:

a. Pendataan Pam Swakarsa;

b. Pemberian kartu tanda anggota dan penggunaan seragam serta atribut bagi personel satuan pengamanan;

c. Pendataan senjata api, amunisi dan kelengkapannya; d. Izin operasional badan usaha di bidang jasa pengamanan; dan

e. Operasionalisasi jasa pengamanan.

Dalam pelaksanaan tugasnya sebagai pengemban fungsi kepolisian terbatas, Satpam berperan sebagai:

a. Unsur pembantu pimpinan organisasi, perusahaan dan/atau instansi/ lembaga pemerintah, pengguna Satpam di bidang pembinaan keamanan dan ketertiban lingkungan/tempat kerjanya;

b. Unsur pembantu Polri dalam pembinaan keamanan dan ketertiban masyarakat, penegakan peraturan perundangundangan serta menumbuhkan kesadaran dan kewaspadaan keamanan (security mindedness dan security awareness) di lingkungan/tempat

1. Pengertian Perusahaan Penyedia Jasa

Alih Daya (Outsourcing) adalah:

"pemindahan atau pendelegasian beberapa proses bisnis kepada suatu badan penyedia jasa dimana badan penyedia jasa tersebut melakukan proses administrasi dan manajemen berdasarkan defenisi yang disepakati para pihak."

Gagasan awal berkembanganya outsourcing adalah membagi resiko usaha dalam berbagai masalah termasuk ketenagakerjaan. Outsourcing merupakan bisnis kemitraan dengan tujuan memperoleh keuntungan bersama membuka peluang bagi berdirinya perusahaan- 
perusahaan baru di bidang jasa penyedia tenaga kerja serta efisiensi bagi dunia usaha.

Outsourcing merupakan salah satu cara pemerintah untuk mempermudah menjalankan usaha ditengah krisis ekonomi yang melanda Negara Indonesia sejak beberapa tahun terakhir. Dalam sistem perekrutan pekerja yang dialihkan kepada pihak lain dengan sistem outsourcing. Dengan sistem ini perusahaan dianggap bisa menghemat pengeluaran dalam membiayai sumber daya manusia yang bekerja di perusahaan yang bersangkutan. Pada waktu itu Pemerintah dianggap bisa menyediakan kesempatan kerja yang banyak bagi banyak pengangguran sehingga adaptasi pasar kerja dan fleksibilitas.

Penyediaan jasa pekerja/buruh untuk kegiatan jasa penunjang atau kegiatan yang tidak berhubungan langsung dengan proses produksi harus memenuhi syarat sebagai berikut:

1. Adanya hubungan kerja antara pekerja/buruh dan perusahaan penyedia jasa pekerja/buruh;

2. Perjanjian kerja yang berlaku dalam hubungan kerja sebagaimana dimaksud pada huruf a adalah perjanjian kerja untuk waktu tertentu yang memenuhi persyaratan sebagaimana dimaksud dalam Pasal 59 dan atau perjanjian kerja waktu tidak tertentu yang dibuat secara tertulis dan ditanda tangani oleh kedua belah pihak;

3. Perlindungan upah dan kesejahteraan syarat-syarat kerja serta perselisihan yang timbul menjadi tanggungjawab perusahaan penyedia jasa pekerja/buruh; dan

4. Perjanjian antara perusahaan pengguna jasa pekerja/buruh dan perusahaan lain yang bertindak sebagai perusahaan penyedia jasa pekerja/buruh dibuat secara tertulis dan wajib memuat pasalpasal sebagaimana dimaksud dalam undang-undang ini.

Pada perusahaan yang berhubungan dengan kegiatan usaha pokok atau kegiatan yang berhubungan langsung dengan proses produksi pengusaha hanya diperbolehkan mempekerjakan pekerja/buruh dengan perjanjian kerja waktu tertentu dan/atau perjanjian kerja waktu tidak tertentu.

Outsourcing di Indonesia adalah pemborongan pekerjaan dan penyediaan jasa tenaga kerja. Diatur dalam Undang-undang Ketengakerjaan Nomor 13 Tahun 2003 yakni Pasal 64, 65 dan 66 dan Keputusan Menteri Tenaga Kerja dan Transmigrasi

Nomor 101/menteri/VI/2004 Tahun 2004 tentang Tata Cara Perijinan Perusahaan Penyedia Jasa Pekerja/Buruh.

Ada 2 macam jenis outsourcing yaitu:

1. Pemborongan Pekerjaan

2. Penyedia Jasa Pekerja/Buruh

Setiap perusahaan biasanya punya syarat spesifik jika satpam atau security tersebut ditugaskan menjaga sesuatu yang spesifik juga. Ada 7 (Tujuh) syarat menjadi satpam, antara lain:

1. Warga negara indonesia. 
2. Tes jasmani dan tes kesehatan.

3. Pendidikan terakhir. Untuk pendidikan terakhir calon satpam minimal memiliki ijazah sekolah menengah atas atau sederajat.

4. Tinggi badan dan berat badan minimal. Misalnya, postur tinggi badan calon satpam laki-laki itu minimal $165 \mathrm{~cm}$ dan untuk calon satpam perempua minimal $160 \mathrm{~cm}$. Namun ini bukan patokan. Ada juga satpam pendek. Terutama untuk satpam perempuan, syarat tinggi badan bisa lebih rendah.

5. Usia minimal dan maksimal. Satpam perumahan mungkin tidak terlalu mensyaratkan usia. Namun satpam gudang atau gedung perkantoran biasanya ada syarat usia.

6. Tes psikotes.

7. Bebas dari narkoba.

Syarat-syarat di atas standar saja. Biasanya, perusahaan akan memberikan syarat yang formal, seperti pendidikan satpam. Satpam untuk menjaga front office juga berbeda yang biasanya jaga malam. Karena memang kerjaannya beda. Yang jaga FO dicari yang ramah dan kelihatan bersih mukanya, agar tidak menakuti customer. Satpam bank juga ada syarat khusus, karena mereka juga harus tahu produk bank dan layanan yang diberikan agar ketika pelanggan bertanya bisa memberikan informasi dengan tepat. Sektor jasa memang lebih butuh satpam dengan pengetahuan dan sikap ramah. Beda dengan penjaga gudang, yang dibutuhkan kadang fisik untuk menangani pencurian.
Dalam Pasal 27 ayat 2 UU Nomor 13 tahun 2003 tentang Ketenagakerjaan merupakan diwujudkan dalam berbagai peraturan perundang-undangan. Yakni pasal 64,65 dan 66 .

Pasal 64

Perusahaan dapat menyerahkan sebagian pelaksanaan pekerjaan kepada perusahaan lainnya melalui perjanjian pemborongan pekerjaan atau penyediaan jasa pekerja/buruh yang dibuat secara tertulis.

Pasal 65

1. Penyerahan sebagaian pelaksanaan pekerjaan kepada perusahaan lain dilaksanakan melalui perjanjian pemborongan pekerjaan yang dibuat secara tertulis.

2. Pekerjaan yang dapat diserahkan kepada perusahaan lain sebagaimana dimaksud pada ayat (1) harus memenuhi syarat-syarat sebagai berikut : a. Dilakukan secara terpisah dari kegiatan utama ; b. Dilakukan dengan perintah langsung atau tidak langsung dari pemberi pekerjaan ; c. Merupakan kegiatan penunjang perusahaan secara keseluruhan ; dan d. Tidak menghambat proses produksi secara langsung.

3. Perusahaan lain sebagaimana dimaksud pada ayat (1) harus berbentuk badan hukum;

4. Perlindungan kerja dan syarat-syarat kerja bagi pekerja/buruh pada 
perusahaan lain sebagaimana

dimaksud pada ayat (2) sekurang-kurangnya sama dengan perlindungan kerja dan syarat-syarat kerja pada perusahaan pemberi pekerjaan atau sesuai dengan peraturan perundangundangan yang berlaku.

5. Perubahan dan/atau penambahan syarat-syarat sebagaimana dimaksud pada ayat (2) diatur lebih lanjut dengan Keputusan Menteri.

6. Dalam hal ketentuan sebagaimana dimaksud pada ayat (2), dan ayat (3), tidak terpenuhi, maka demi hukum status hubungan kerja pekerja/buruh dengan perusahaan penerima pemborongan beralih menjadi hubungan kerja pekerja/buruh dengan perusahaan pemberi pekerjaan.

Pada pekerjaan yang berhubungan dengan kegiatan usaha pokok atau kegiatan yang berhubungan langsung dengan proses produksi, pengusaha hanya diperbolehkan mempekerjakan pekerja/buruh dengan perjanjian kerja waktu tertentu dan/atau perjanjian kerja waktu tidak tertentu.

dijelaskan apa yang dimaksud dengan pernyerahan sebagain pekerjaan, perjanjian pemborongan dan penyediaan jasa pekerja serta perusahaan lain. Dalam ketentuan penjelasan pun isinya cukup. Dalam konsep hukum, hubungan kerja ini sangat penting karena hubungan kerja yang timbul dengan adanya perjanjian kerja akan melahirkan hak dan

kewajiban para pihak. Para pihak menurut pasal 1 ayat (15) jelas adalah pekerja

dan pengusaha/pemberi kerja. Sementara dalam outsourcing pekerja melakukan

perjanjian bukan dengan pengusaha pemberi kerja, sedangkan perjanjian kerja antara pekerja dengan perushaan penyedia jasa tidak ada unsur pekerjaan karena

yang mempunyai pekerjaan adalah pengusaha pemberi kerja. Karena unsur hubungan kerja tidak terpenuhi maka hak dan kewajiban tidak pula akan ada.

Pengaturan sanksi yang tidak ada, kalaupun ada tidak jelas apa yang diancam oleh sanksi tersebut. Hal ini dapat dilihat pada pasal 188 Barang siapa melanggar ketentuan sebagaimana dimaksud dalam Pasal 64 ayat (1) dikenakan sanksi pidana denda paling sedikit Rp 5.000.000,00 (lima juta rupiah) dan paling banyak Rp 50.000.000,00 (lima puluh juta rupiah). Ketentuan pasal 64 tidak terdiri ayat-ayat karena pasalnya tunggal, sementara dalam pengaturan sanksi yang diancam dengan sanksi pidana adalah terhadap pasal 64 ayat (1). Jadi pengaturan dalam UU Ketenagakerjaan tidak sinkron antara pasal yang satu dengan yang lain.

Sistem outsourcing telah membuka peluang munculnya perusahaan baru di bidang jasa outsourcing, dan pada sisi lain telah memungkinkan perusahaan yang telah berdiri untuk melakukan efisiensi melalui pemanfaatan jasa perusahaan outsourcing. Untuk menerapkan atau melaksanaan outsoucing ini dengan persyaratan yang sangat ketat dapat dilihat dalam ketentuan pasal 65-66.

Pasal 64 UU No 13 Tahun 2003 yang berbunyi: 


\begin{abstract}
Perusahaan dapat menyerahkan sebagian pelaksanaan pekerjaan kepada perusahaan lainnya mellaui perjanjian pemboorngan pekerjaan atau penyediaan jasa pekerja / buruh yang dibuat tertulis.
\end{abstract}

Kaitannya dengan ketenagakerjaan dalam pemborongan pekerjaan ini terdapat 2 jenis perusahaan adalah:

1. Perusahaan utama yaitu perusahaan yang menyerahkan pekerjaan disebut outsourcer;

2. Perusahaan yang menerima pekerjaan dari perusahaan utama untuk dilaksanakan yang disebut outsourcee.

Dengan adanya sistem outsourcing tersebut perusahaan penyedia jasa yang melakukan fungsi jasa yang dahulu pernah menjadi bagian tak terpisahkan dari perusahaan. Out soursing, yaitu suatu perjanjian yang dilakukan antara suatu perusahaan dengan perusahaan penyedia jasa tenaga kerja, untuk suatu pekerjaan tertentu. Disini pihak pekerja/buruh mengadakan perjanjian kerjanya bukan dengan perusahaan dimana mereka bekerja, akan tetapi mereka membuat perjanjian kerjanya dengan perusahaan penyedia jasa tenaga kerja. Demikian juga pemberian upahnya-pun diberikan oleh perusahaan penyedia jasa tenaga kerja tersebut. Mereka biasanya dikontrak selama dua tahun, dan dapat diperpanjang satu tahun lagi. Sehingga lamanya 3 Tahun. Kalau akan diperpanjang kontrak kerjanya maka otomatis dia menjadi tenga kerja tetap, yang bekerja di perusahaan tersebut. Permasalahannya bahwa waktu kerja kontrak ini terus menerus dilakukan, sehingga sangat merugikan bagi buruh/pekerja yang keadaannya sangat lemah.

Perusaahaan penyedia jasa kemudia disebut vendor sedangkan perusahaan yang memberikan pekerjaan kepada vendor disebut istilah user. Vendor melakukan rekruitmen calon pekerja dengan berbagai cara misalnya dengan memasang iklan di surat kabar dan kantor pos karena kantor pos operasional sampai di kota-kota kecil. Bahkan vendor bekerjasama dengan sekolah-sekolah kejuruan untuk mencari bibit unggul.

Hubungan kerja dengan sistem outsourcing ini menyebakan kedudukan para pihak menjadi tidak seimbang dan menimbulka rasa khawatir kepada pekerja sehingga pekerja berada disisi yang lemah. Pada awalnya fungsi jasa yang dikontrakan kepada pihak luar adalah bidang kebersihan dan catering, lama kelamaan bidang keamanan, transaportasi dan lain-lain. Bahkan kemudian masuk kepabrik-pabrik yaitu pada bagian produksi.

Lembaga Pendidikan dan Pelatihan Satpam yang diadakan oleh Pemerintah maupun swasta sangat dibu-tuhkan dan sangat efektif untuk melatih dan mendi-dik calon petugas satpam sebelum ditempatkan dan dipekerjakan di lingkungan tempat kerjanya, seperti: PT Golgon, PT. Scoricor, PT. Mahakam Merah Padi, PT. Jaga Raga, PT. Mitra Karya Utama Sentosa, PT. Sigap Prima Astrea (SPA), PT. Group 4 Securitas Indone-sia dan lembaga-lembaga pendidikan yang lain. 
Pendidikan dan Pelatihan satpam sebagai tenaga keamanan di lingkungan perusahaan akan menciptakan petugas satpam yang mempunyai kemampuan (skill) di bidang pekerjaannya dan akan menambah skill) di bidang pekerjaannya dan akan menambah skilletos kerja serta meningkatkan tingkat intelegensinya (kecerdasan), sehingga akan lebih cepat dan tanggap dalam mengantisipasi setiap gangguan kamtibmas serta permasalahan yang terjadi, dan setiap petugas satpam yang bekerja di perusahaan sungguh-sung-guh dapat dipercaya untuk melaksanakan peran dan fungsinya sebagai tenaga keamanan dengan sangat efektif dan penuh tanggung jawab, dan dapat mem-berikan dorongan semangat serta gairah kerja bagi segenap jajaran anggota petugas satpam di tempat kerjanya yang akhirnya dapat lebih mampu untuk meningkatkan kiprah pengabdiannya kepada perusa-haan, negara dan bangsa.

\section{KRITERIA PIDANA DILAKUKAN \\ TINDAK YANG OUTSOURCING DAN SANKSI YANG DIKENAKAN KEPADA PEKERJA OUTSOURCING}

Kewenangan yang dilakukan oleh petu-gas satpam hanyalah merupakan tindakan awal agar pelaku tidak melarikan diri atau tidak menimbul-kan dampak yang lebih besar kepada perusahaan dan menghindari jangan sampai terjadi ada pihak-pihak yang main hakim sendiri.

Pelaku yang sudah tertangkap tangan secepatnya diserah-kan kepada pihak Polri setempat yang mempunyai hak dan kewenangan untuk menyelidiki dan menyi-dik serta menahan pelaku kejahatan atau pelanggaran yang telah dilakukan, tindakan petugas satpam bisa dilakukan bila terjadi tindak pidana yang tertangkap tangan, sehingga kewenangan petugas satpam dapat melakukan tindakan upaya paksa untuk menegakkan hukum di lingkungan kerjanya yang sifatnya sementara, Pasal 1 angka 19 dan 111 ayat (1) No. 8 Tahun 1981 Kitab Undang Undang Hukum Acara Pidana, yang dikatakan tertangkap tangan yaitu:

a. Tertangkap-nya seseorang pada waktu sedang melakukan tindak pidana;

b. Atau dengan segera sesudah beberapa saat tindak pidana itu dilakukan;

c. Atau sesaat kemudian diserukan oleh khalayak ramai sebagai orang yang melakukan;

d. Sesaat kemudian padanya ditemukan benda yang diduga keras telah dipergunakan melakukan tindak pidana yang menunjukkan bahwa ia adalah pelakunya atau turut melakukan atau mem-bantu melakukan tindak pidana.

Perusahaan PT Golgon banyak kehilangan besi, kabel-kabel instalansi yang memiliki tembaga. Banyak juga satpam mencuri bagian ini. Kalau di perkantoran, pencurian uang yang disimpan di laci karyawan, dilakukan oleh satpam yang menjaga pada malam hari.

Biasanya pada malam hari, hasil barang curian disimpan dan dikeluarkan dan ketahuan dari CCTV maka pelakunya ketahuan dari kroscek maka pihak penyedia jasa meminta pertanggungjawabannya dari pelaku pencurian kabel atau 
potongan besi. Jika ada kejadian pencurian tersebut maka, sebagai perusahaan hanya berhadapan dengan penyedia jasa, masalah ke polisi tidak akan dicampuri lagi.

Perusahaan melakukan usaha untuk bertanggungjawab atas tindak pidana yang dilakukan pekerja tetapi hanya sebatas hukum perdata. Misalnya, akibat pencurian besi tadi dikembalikan ke perusahaan yang mencuri. Tapi pekerja sendiri bertanggungjawab sendiri secara penuh di muka pengadilan.

$$
\text { Dalam rekaman CCTV }
$$

didalam gudang terlihat penjaga gudang didatangi kawanan khusus pencurian. Setiap sekuriti akan mempunyai peran masing-masing salah satunya menawarkan kerjasama dengan keamanan gudang satu bulan sebelum beraksi.

Jika ada perkelahian didalam perusahaan, yang diatasi oleh satpam adalah:

1. Usahakan melerai, memisahkan para pelakunya dengan peringatan untuk mengalihkan perhatian

2. Apaila dalam perkelahian tersebut digunakan alat-alat berbahaya usahakan pemisahan itu diarahkan kepada salah satu pihak yang menggunakan senjata;

3. Dalam perkelahian kelompok; usahakan memberi peringatan yang dapat menarik dan mengalihkan perhatian para pelaku, dan meminta bantuan masyarakat untuk dapat memisahkan kelompok yang berkelahi.

Petugas Satpam sebagai tenaga keamanan dan penegakan hukum di lingkungan perusahaan tempat kerjanya apabila terjadi tindak pidana yang tertangkap tangan, harus benar-benar memperhatikan hal-hal sebagai berikut:

a. Tidak bertentangan dengan suatu aturan hukum;

b. Selaras dengan kewajiban hukum yang mengharus-kan tindakan tersebut dilaksanakan;

c. Harus patut, masuk akal, termasuk dalam lingkup kewenangannya;

d. Pertimbangan yang layak berdasarkan keadaan yang memaksa dan menghormati hakhak asasi manusia.

Kewenangan petugas satpam pada waktu melak-sanakan tugas umumnya sama dengan yang dilakukan oleh Polri, tetapi pada tingkatan prinsipilnya pelak-sanaan tugas dan fungsi yang dilakukan oleh petugas satpam ada perbedaannya kewenangan.

Bentuk kewenangan terbatas yang diberikan pada petugas satpam di perusahaan merupakan suatu aturan yang harus dipatuhi dan dipahami serta dilaksanakan dengan prosedur yang benar meskipun hanya mempunyai ruang lingkup kewenangan kuasa tempat dan tidak memiliki ruang lingkup kewenangan kuasa yang termasuk kewenangan hukum publik, seperti; menuntut, menyidik maupun menahan, hal ini ditegaskan di dalam Penjelasan Pasal 3 huruf c Undang-Undang Republik Indonesia Nomor 2 Tahun 2002 tentang Kepolisian Negara Republik Indonesia, bahwa petu-gas satpam merupakan "bentuk-bentuk peng amanan swakarsa" adalah suatu bentuk peng-amanan yang diadakan atas kemauan, kesadaran, dan kepentingan masyarakat sendiri yang 
kemudian memperoleh pe-ngukuhan dari Kepolisian Negara Republik Indonesia, seperti satuan pengamanan lingkungan dan badan usaha di bidang jasa peng amanan.

Bentuk-bentuk pengamanan swakarsa memiliki kewenangan Kepolisian Negara terbatas dalam "Lingkungan kuasa tempat" (teritoir gebied/teritoir gebied/teritoir gebiedruimte gebied) meliputi lingkungan ruimte gebied) meliputi lingkungan ruimte gebiedpemukiman, lingkungan kerja, lingkungan pendidikan. Contohnya adalah satuan pengamanan lingkungan di pemukiman, satuan pengamanan pada kawasan perkantoran atau satuan pengamanan pada pertokoan.

Jika ada pencurian dilingkungan satpam tempat bekerja, maka yang perlu diperhatikan adalah sebagai berikut:

a. Lakukan peneguran kepada yang bersangkutan seperlunya.

b. Bila yang bersangkutan mengadakan perlawanan segera mengambil langkah sebagai berikut:

1. Dalam menghadapi pelaku kejahatan harus selalu waspada dan jangan melakukan tindakan yang ceroboh sehingga dapat menimbulkan kerugian diri sendiri.

2. Jika pelakunya seorang dan bisa diatasi segera diadakan penangkapan.

3. bila pelakunya lebih dari 1 orang segera hubungi anggota satpam lainnya dengan melalui alat telekomunikasi yang berlaku / ada dan bila perlu mengadakan penangkapan terhadap pelaku tersebut.

c. Dalam waktu bersamaan anggota satpam lainnya menghubungi pos Polisi terdekat melalui telepon atau alat komunikasi lainnya.

d. Setelah diadakan penangkapan segera pelakunya diamankan berikut barang bukti bila ada.

e. Jangan sekali-kali mengadakan pemukulan / menghakimi sendiri.

f. Bila memungkinkan segera dibawa ke Pos Polisi terdekat atau setidak-tidaknya memberitahukan kepada Polri tersebut.

g. Kemudian segera membuat laporan pada buku mutasi penjagaan.

Kemampuan yang Harus Dimiliki oleh Seorang Satpam, meliputi:

a. kepolisian terbatas;

b. keselamatan dan keamanan lingkungan kerja;

c. pelatihan/kursus spesialisasi dibidang Industrial Security.

Kemampuan/kompetensi anggota Satpam sebagai pengemban fungsi Kepolisian Terbatas, diperoleh melalui pelatihan Satpam pada Lembaga Pendidikan Polri maupun Badan Usaha Jasa Pengamanan (BUJP) yang telah mendapatkan izin dari Kapolri. Sedangkan kemampuan keselamatan dan keamanan lingkungan kerja terdiri dari 3 (tiga) jenjang pelatihan yaitu:
a. Gada Pratama untuk kemampuan dasar;
b. Gada Madya untuk kemampuan menengah; dan


c. Gada Utama untuk kemampuan manajerial.

Kemampuan teknis keselamatan dan keamanan lingkungan kerja, diperoleh melalui pelatihan in house training pada tempat dimana anggota Satpam bertugas. Pelatihan/Kursus Spesialisasi, berkaitan dengan bidang tugasnya yang diatur secara spesifik baik teknis maupun cakupannya, oleh ketentuan peruntukannya. Pelatihan pelatihan/kursus spesialisasi dibidang Industrial Security dan keselamatan dan keamanan lingkungan kerja merupakan kewajiban dari instansi/badan/penyelenggara dan pengguna Satpam.

Pelatihan Gada Pratama dan Gada Madya diselenggarakan oleh:

a. lembaga pendidikan di lingkungan Kepolisian Republik Indonesia ("Polri")

b. Badan Usaha Jasa Pengamana ("BUJP") yang mempunyai izin operasional pelatihan dari Kepala Kepolisian Republik Indonesia ("Kapolri”).

Pelatihan Gada Utama penyelenggaraannya dikendalikan oleh Mabes Polri. Kemudian untuk pelatihan/kursus spesialisasi diselenggarakan oleh:

a. Polri;

b. in house training oleh pengguna jasa dan/atau instansi terkait;

c. instansi/pengguna Satpam terkait dan/atau BUJP yang mendapat izin atau akreditasi untuk melakukan pelatihan dimaksud.
Kemudian terkait dengan apakah ada perbedaan tugas satpam pada setiap organisasi, perusahaan dan/atau instansi/lembaga pemerintah, perlu diketahui berdasarkan Perkapolri 24/2007 telah dijelaskan tugas-tugas seorang satpam. Namun, kembali lagi bahwa setiap organisasi, perusahaan dan/atau instansi/lembaga pemerintah memiliki standar sistem manajemen pengamanan yang berbeda.

Seragam Satpam (Gam Satpam) adalah pakaian yang dilengkapi dengan tanda pengenal dan atribut tertentu sesuai aturan dari kepolisian sebagai pengawas dan pembina teknis Satpam yang dipakai dan digunakan oleh anggota Satpam serta telah mendapat pengakuan dari Polri untuk dapat melaksanakan tugas sebagai pengemban fungsi kepolisian terbatas pada lingkungan kerjanya. Gam Satpam terdiri dari:

a. Gam Satpam Pakaian Dinas Harian ("PDH");

Gam Satpam PDH adalah Gam Satpam yang dipakai dan digunakan untuk melaksanakan tugas sehari-hari di lingkungan kerjanya, selain di kawasan khusus yang memerlukan kelengkapan seragam khusus.

b. Gam Satpam Pakaian Dinas Lapangan ("PDL");

Gam Satpam PDL adalah Gam Satpam yang khusus digunakan pada area yang banyak berhubungan kegiatan di lapangan dan sejenisnya.

c. Gam Satpam Pakaian Sipil Harian ("PSH"); dan 
Gam Satpam PSH adalah Gam Satpam yang dipakai dan digunakan untuk melaksanakan tugas harian di area kerjanya yang banyak berhubungan dengan pelanggan, masyarakat umum serta petugas yang membidangi pengamanan non fisik, yang diberikan kepada petugas setingkat supervisor ke atas.

d. Gam Satpam Pakaian Sipil Lapangan ("PSL").

Gam Satpam PSL adalah Gam Satpam yang dipakai dan digunakan untuk melaksanakan tugas pengamanan event.

Sebagai informasi, penggunaan Gam Satpam hanya dibenarkan dalam melaksanakan tugas pengamanan di lingkungan/tempat kerjanya. Penggunaan Gam Satpam di luar lingkungan/tempat kerjanya diwajibkan membawa Surat Perintah Tugas atasannya. Selain itu, dapat melihat Kartu Tanda Anggota (KTA) Satpam yang merupakan sebagai identitas kewenangan melaksanakan tugas pengemban fungsi kepolisian terbatas di lingkungan kerjanya. KTA wajib diperlihatkan apabila diperlukan untuk membuktikan kewenangan yang dimiliki pemegangnya.

\section{TANGGUNGJAWAB} PERUSAHAAN PENYEDIA JASA AKIBAT TINDAK PIDANA YANG DILAKUKAN PEKERJA OUTSOURCING

Pekerja melakukan kesalahan berat. Kesalahan apa saja yang termask dalam kategori kesalahan berat adalah pekerja telah melakukan: a Penipuan, pencurian, penggelapan barang dan uang milik perusahaan. pekerja memberikan keterangan palsu atau yang dipalsukan sehingga merugikan perusahaan.

b Pekerja mabuk-mabukan, minum-minuman keras, memakai atau mengedarkan narkotika, dan zat aktif lainnya dilingkungan pekerja.

c Melakukan perbuatan asusila atau perjudian di lingkungan kerja.

d Menyerang, menganiaya, mengancam atau mengintimidasi teman sekerja atau perusahaaan di lingkungan kerja.

e Dengan ceroboh atau sengaja membiarkan teman sekerja atau perusahaan dalam keadaan bahaya di tempat kerja.

f Melakukan perbuatan lainnya dilingkungan perusahaan yang diancam hukuman pidana penjara 5 tahun atau lebih.

Perusahaan melakukan usaha untuk bertanggungjawab atas tindak pidana yang dilakukan pekerja tetapi hanya sebatas hukum perdata. Misalnya, akibat pencurian besi tadi dikembalikan ke perusahaan yang mencuri. Tapi pekerja sendiri bertanggungjawab sendiri secara penuh di muka pengadilan.

Pencurian biasa adalah mengambil barang miliki orang lain tanpa izin. Pencurian yang dilakukan pada malam hari belum tentu masuk dalam kategori perampokan oleh sebab itu dilihat dahulu apakah terdapat unsur kekerasan atau ancaman kekerasan sehingga patut dibedakan pencurian biasa dengan pencurian pasal pemberatan pada malam hari atau dengan anak kunci palsu. 
Pencurian biasa dibagi menjadi 2 pencurian non ringan dan pencurian ringan. Dipidana paling banyak Sembilan ratus rupiah atas pidana penjara paling lama 5 tahun.

Pekerja yang ditempatkan pada perusahaan penyedia pekerjaan tidak menjadi tanggun jawab dari perusahaan penyedia pekerjaan atau bukan pada pekerjaan yang menimbulkan permasalahan pencurian yang dapat merugikan pihak lain. Perlu adanya batasan yang tegas tentang bagaiamana atau sejauh mana pertanggungjawaban perusahaan dalam hal pekerjaanya melakukan perbuatan melawan hukum. Aturan khusus yang dimiliki oleh perusahaan dan wajib untuk dilaksanakan oleh pekerja secara khusus. Ketika hal diatas dilanggar maka setiap pihak yang melanggar akan dikenaka sanksi atau konsekuensi dari setiap perbuatan yang dilakukan:

a Sanksi berupa denda. Pada pasal 95 ayat 1 UU No 13 Tahun 2003 berbunyi pelanggaran yang dilakukan oleh pekerja/buruh karena kesengajaan atau kelalaiannya dapat dikenakan denda. Sebenarnya diserahkan kepada pihak pengusaha dan pekerja untuk disepakati bersama dalam bentuk perjanjian kerja, peraturan perusahaan dan juga perjanjian kerja bersama.

b Sanksi berupa pemutusan kerja, berupa:

- Pengunduran diri secara baikbaik atas kemauan sendiri

- Pengunduran diri secara terulis atas kemauan sendiri karena berakhirnya hubungan kerja. Bagi pekerja kontrak yang mengundurkan diri karena masa kontrak berakhir maka pekerja tidak mendapat uang pesangon sesuai ketentuan pasal 154 ayat 2 dan uang penghargaan masa kerja sesuai ketentuan pasal 156 ayat 3 uang pisah tetapi berhak atas penggantian hak sesuai ketentuan pasal 156 ayat 4 .

- Pengunduran diri karena mencapai uang pensiun.

Dalam kasus satpam yang mencuri, pernah terjadi di Semboro Jember, Jawa timur. Pada Perusahan PG Semboro, ada 4 satpam kepergok mengeluarkan besi dan kuningan. Ada 460 batang pipa kuningan, sejumlah besi dengan berat mencapai $2450 \mathrm{~kg}$ satu unit mobil pikap dan 11 handphone. Pencurian yang dilakukan satpam ini sudah terjadi sejak tahun 2019 di pabrik tempat dia bekerja. Pada kasus ini, manajemen PT PG Semboro sudah menyerahkan sepenuhnya kepada kepolisian untuk melakukan penyelidikan, sebab tidak menutup kemungkinan ada pihakpihak lain yang terlibat dalam aksi pencurian ini. Dan pada perusahaan vendor mereka sendiri dilakukan pemecatan.

Pihak pengusaha tetap berkewajiban memberi kompensasi pesangon dan hak normatif lainnya sebesar 1 kali ketentuan PHK normal. Kecuali bila pelanggaran yang dilakukan pekerja dalam bentuk pelanggaran serius yang melukai hubungan kepercayaan dan penyalahgunaan itikad baik relasi antara pihak pengusaha dan pekerja sperti melakukan tindak pidana penggelapan, tindak pidana pencurian yang mengakibatkan kerugian besar pada keuangan pengusaha maka berdasarkan asas kepatutan dan proposionalitas pengusaha tidak memiliki beban moril atau 
kompensasi apapun untuk memutus hubungan kerja.

\section{KESIMPULAN}

A Pengaturan Hukum Satpam menurut peraturan perundangundangan di Indonesia diatur dalam Pasal 3 ayat 1 huruf $\mathrm{c}$ Undang-undang Nomor 2 Tahun 2002 tentang Kepolisian, dimaksud dengan bentuk-bentuk pengamanan swarkasa seperti satuan pengamanan satpam lingkungan dan badan usaha di bidang jasa pengamanan. Satpam juga dapat dilihat dari Peraturan Kepala Kepolisian Negara Nomor 24 Tahun 2007 tentang Sistem Manajemen Pengamanan Organisasi, Perusahaan dan/atau Lembaga Pemerintah.

B Kriteria Tindak Pidana Yang Dilakukan Pekerja Satpam Dan Sanksi Yang Dikenakan Kepada Pekerja Satpam harus disesuaikan dengan Standar Operating Prosedure yang menjadi pokok pelaksanaan kegiatan pengamanan yang didalamnya terdapat aturanaturan mengenai prosedur dan standar serta sanski yang dapat diberikan. Misalnya pasal 351 KUHP satpam tersebut dapat dilaporkan agar dapat diberikan sanksi asosiasi dari Badan Usaha Jasa Pengamanan (BUJP) agar dapat mempekerjakannya.

C Tanggungjawab Perusahaan Penyedia Jasa Akibat Tindak Pidana Yang Dilakukan Pekerja Satpam memberikan hak sepenuhnya kepada Kepolisian untuk melakukan penyelidikan, dan hak-hak sebagai satpam pada perusahaan tersebut putus.

\section{Buku-buku}

Arief, Barda Nawawi, 2003, Kapita Selekta Hukum Pidana, Bandung: Citra Aditya Bakti. 1998, TeoriTeori dan Kebijakan Pidana ,Bandung: Alumni.

Eddy, Hiariej O.S., 2014, Prinsipprinsip Hukum Pidana, Yogyakarta: Cahaya Atma Pustaka

Hanafi, 1997, Strict Liability dan Vicarious Liability, dalam "Hukum Pidana", Yogyakarta: Lembaga Penelitian, Universitas Islam Indonesia

Ilham, Gunawan, 1992, Penegakan Hukum dan Penegak Hukum, Bandung: Angkasa.

Ibrahim, Johnny, 2007, Teori dan Metodologi Penelitian Hukum Normatif, Malang: Bayumedia Publishing.

Kristian, 2015, "Hukum Pidana Korporasi”, Bandung: Nuansa Aulia

Mahrus Ali, 2013, Asas-asas Hukum Pidana Korporasi, Rajawali Pers, Jakarta

Moeljatno, 2008, Azas-azas Hukum Pidana, Rineka Cipta, Jakarta.

Maramis, Frans, 2012, Hukum Pidana Umum dan Tertulis di Indonesia, Jakarta : Rajawali Pers

\section{DAFTAR PUSTAKA}


Pramono, Nindyo, 2006, "Bunga Rampai Hukum Bisnis Aktual", Bandung: PT.Citra Aditya Bhakti

Priyatno, Dwidja, 2004, "Kebijakan Legislasi Tentang Sistem Pertanggungjawaban Pidana Korporasi Di Indonesia”, Bandung, CV Utomo.

2010

Pertanggungjawaban Pidana Korporasi, Jakarta: Kencana Prenadamedia Group.

Remi, Sjahdeini Sutan, 2006, "Pertanggungjawaban

Pidana Korporasi”, Jakarta: Grafiti Pers

Soepomo, Imam, 1995, Pengantar Hukum Perburuhan, Jakarta: Jambatan.

Sjawie, Hasbullah F, 2013, Direksi Perseroan Terbatas serta Pertanggungjawaban Pidana Korporasi, Bandung: PT Citra Aditya Bakti.

\section{Peraturan Perundang-undangan}

Undang-Undang Nomor 21 Tahun 2000 Tentang Serikat Pekerja/Serikat Buruh

Undang-Undang Nomor 13 Tahun 2003 tentang Ketenagakerjaan

Undang-undang Nomor 2 Tahun 2003 tentang Kepolisian

Surat Keputusan Kepala Kepolisian No Pol: Skep/1017/XII/2002 tentang Kurikulum Pelatihan Satuan Pengamanan.

Surat Keputusan Kepala kepolisian No Skep/1020/XII/2002 tentang Registrasi Satuansatuan Pengamanan

Peraturan Kepala Kepolisian No 24 Tahun 2007 tentang Sistem Manajemen Pengamanan Organisasi Perusahaan dan Instansi

Peraturan Menteri Tenaga Kerja dan Transmigrasi Nomor 19 Tahun 2012 tentang SyaratSyarat Penyerahan Sebagian Pelaksanaan Pekerjaan Kepada Perusahaan Lain

Surat Edaran Menteri Tenaga Kerja dan Transmigrasi Nomor SE.04/MEN/VIII/2013 tentang Pedoman Pelaksanaan Peraturan Menteri Tenaga Kerja dan Transmigrasi Nomor 19 Tahun 2012 tentang Syarat-Syarat Penyerahan Sebagian Pelaksanaan Pekerjaan Kepada Perusahaan Lain.

\section{Internet/Kamus Hukum/Jurnal}

https://www.hukumonline.com/k linik/detail/ulasan/lt50a0693a722b5/ pemukulan-penganiayaan/ diakses tanggal 09 Maret 2020

https://www.hukumonline.com/k linik/detail/1t5b56add032c89/batasan -kewenangan-satuan-pengamanansatpam-dalam-menggeledahseseorang/ diakses tanggal 09 Maret 2020

Jurnal Perspektif, Volume XVI No 3 Tahun 2011 Edisi Mei diakses dalam

https://ejournal.uwks.ac.id/myfiles/2 01207081310382587/11.pdf tanggal 10 Juli 2020. 
https://fjp-law.com/id/satpam-

dalam-perspektif-hukum/ diakses tanggal 10 Juli 2020

https://www.hukumonline.com/k linik/detail/ulasan/lt51ee87cd92elf/a kibat-hukum-pelanggaran-praktikioutsourcing-i/ diakses tanggal $10 \mathrm{Juli}$ 2020 